Georgia State University

ScholarWorks @ Georgia State University

\title{
On the Political Determinants of Intergovernmental Grants in Decentralized Countries: The Case of Spain
}

\author{
Pablo Simon-Cosno \\ Universitat Pompeu Fabra \\ Santiago Lago-Penas \\ University of Vigo, slagop@uvigo.es \\ Alberto Vaquero \\ University of Vigo
}

Follow this and additional works at: https://scholarworks.gsu.edu/icepp

Part of the Economics Commons

\section{Recommended Citation}

Simon-Cosno, Pablo; Lago-Penas, Santiago; and Vaquero, Alberto, "On the Political Determinants of Intergovernmental Grants in Decentralized Countries: The Case of Spain" (2012). ICEPP Working Papers. 72.

https://scholarworks.gsu.edu/icepp/72

This Working Paper is brought to you for free and open access by the International Center for Public Policy at ScholarWorks @ Georgia State University. It has been accepted for inclusion in ICEPP Working Papers by an authorized administrator of ScholarWorks @ Georgia State University. For more information, please contact scholarworks@gsu.edu. 
International Center for Public Policy Working Paper 12-30

September 2012
On the Political Determinants of Intergovernmental Grants in Decentralized Countries: The Case of Spain

Pablo Simón-Cosano Santiago Lago-Peñas Alberto Vaquero 

International Center for Public Policy

Working Paper 12-30

\title{
On the Political Determinants of Intergovernmental Grants in Decentralized Countries: The Case of Spain
}

\author{
Pablo Simón-Cosano \\ Santiago Lago-Peñas \\ Alberto Vaquero
}

September 2012

International Center for Public Policy

Andrew Young School of Policy Studies

Georgia State University

Atlanta, Georgia 30303

United States of America

Phone: (404) 651-1144

Fax: (404) 651-4449

Email: hseraphin@gsu.edu

Internet: http://aysps.gsu.edu/isp/index.html

Copyright 2006, the Andrew Young School of Policy Studies, Georgia State University. No part of the material protected by this copyright notice may be reproduced or utilized in any form or by any means without prior written permission from the copyright owner. 


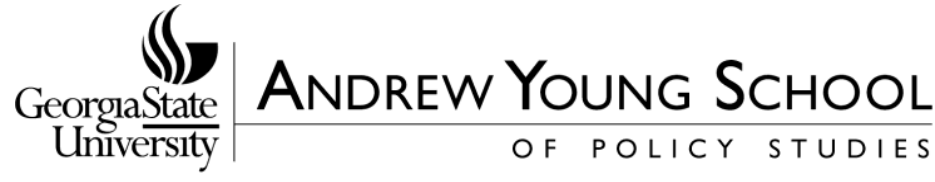

\section{International Center for Public Policy Andrew Young School of Policy Studies}

The Andrew Young School of Policy Studies was established at Georgia State University with the objective of promoting excellence in the design, implementation, and evaluation of public policy. In addition to two academic departments (economics and public administration), the Andrew Young School houses seven leading research centers and policy programs, including the International Center for Public Policy.

The mission of the International Center for Public Policy is to provide academic and professional training, applied research, and technical assistance in support of sound public policy and sustainable economic growth in developing and transitional economies.

The International Center for Public Policy at the Andrew Young School of Policy Studies is recognized worldwide for its efforts in support of economic and public policy reforms through technical assistance and training around the world. This reputation has been built serving a diverse client base, including the World Bank, the U.S. Agency for International Development (USAID), the United Nations Development Programme (UNDP), finance ministries, government organizations, legislative bodies and private sector institutions.

The success of the International Center for Public Policy reflects the breadth and depth of the in-house technical expertise that the International Center for Public Policy can draw upon. The Andrew Young School's faculty are leading experts in economics and public policy and have authored books, published in major academic and technical journals, and have extensive experience in designing and implementing technical assistance and training programs. Andrew Young School faculty have been active in policy reform in over 40 countries around the world. Our technical assistance strategy is not to merely provide technical prescriptions for policy reform, but to engage in a collaborative effort with the host government and donor agency to identify and analyze the issues at hand, arrive at policy solutions and implement reforms.

The International Center for Public Policy specializes in four broad policy areas:

- Fiscal policy, including tax reforms, public expenditure reviews, tax administration reform

- Fiscal decentralization, including fiscal decentralization reforms, design of intergovernmental transfer systems, urban government finance

- Budgeting and fiscal management, including local government budgeting, performancebased budgeting, capital budgeting, multi-year budgeting

- Economic analysis and revenue forecasting, including micro-simulation, time series forecasting,

For more information about our technical assistance activities and training programs, please visit our website at http://aysps.gsu.edu/isp/index.html or contact us by email at hseraphin@gsu.edu. 


\title{
On the Political Determinants of Intergovernmental Grants in Decentralized Countries: The Case of Spain ${ }^{1}$
}

\author{
Pablo Simón-Cosano*, Santiago Lago-Peñas ${ }^{* *}$, and Alberto Vaquero ${ }^{* * *}$ \\ ${ }^{*}$ Universitat Pompeu Fabra \\ ${ }^{* *}$ REDE, IEB and University of Vigo \\ ${ }^{* * *}$ University of Vigo
}

\begin{abstract}
This paper studies the effect of political variables on the gains obtained by Spanish regions in periodical bargaining of the intergovernmental financing agreements and on the regional distribution of discretional earmarked grants over the period 1987-2008. First, we find that the relationship between gains in transferred revenues and on regional public debt stocks depends on the period and the specific issues discussed in the corresponding negotiation, aside from political affinity. Second, we show that the most discretional program of earmarked grants is strongly driven by electoral strategy. National incumbents tend to allocate intergovernmental transfers where there are competitive regional elections. Moreover, we show that earmarked grants are allocated in those regions where the incumbent performs better in national elections and, especially, in those where there are more seats to be won. Hence we prove that both strategies are complementary rather than exclusive.
\end{abstract}

\section{Key words}

Intergovernmental grants, party systems, elections, subcentral public debt.

\footnotetext{
${ }^{1} \mathrm{We}$ are grateful to Ignacio Lago for his insightful comments. The usual disclaimer applies. The research was financially supported by the Spanish Ministry of Science and Innovation [Grant code: ECO201015553].
} 


\section{INTRODUCTION}

A growing body of literature argues that intergovernmental grants in fiscal federalism tend to be allocated according to political interests (Khemani, 2007: 465). Public agents face important incentives in order to use public investment strategically. Nevertheless, the disagreement relies on the implemented strategy. A first set of authors have argued that in districted electoral systems, intergovernmental grants will be allocated in those regions in which there are more seats apportioned (Gibson et al., 1999; Porto and Sanguinetti, 2001; Samuels and Snyder, 2001; Rodden, 2002; Hoover and Pecorino, 2005; Pitlik at al., 2006). Other authors have posited that intergovernmental grants will be allocated exclusively depending on the presence of the same party in charge of the subnational unit (Khemani, 2003, 2007). Finally, another strand of literature has focused on how an electoral race is the central element driving the levels of government investment, whether it is centered on their own strongholds (Cox and McCubbins, 1986) or in breaking a tie in a constituency (Lindbeck and Weibull (1993; Dixit and Londregan, 1996, 1998; Dahlberg and Johansson, 2002).

Previous studies have been specially focused on the incentives encouraging different strategies. However, there still important efforts to be made in two analytical vectors. First, political strategies dealing with intergovernmental grants require considering together the interaction of electoral outcomes and institutional context (León-Alfonso, 2007). Second, the subnational level of competition has received less attention in comparison to the national one. The focus has been particularly centered on political affinity among levels of government (Khemani, 2003; 2007) but the role played by regional elections has not been directly addressed.

Spain provides a perfect case study to deal with these challenges. First, it is an evolving federation characterized up to now by periodical bargaining on its fiscal federal framework. The main issue discussed each time is the amount of total revenues for regions and the criteria to distribute it among those regions. By and large, the main sources of revenues for regional governments are grants (both unconditional and conditional) and tax sharings. Second, Spain is one country with substantial variance in district magnitude across constituencies in national elections (Monroe and Rose, 2002), so it presents a significant within-country variation in incentives for resource allocation. 
Finally, the case of Spain is puzzling. Despite the theoretical expectations, political variables have not been proven especially relevant in some pieces of research (LagoPeñas, 2005; Gómez-Reino y Herrero, 2011) or at best there has been mixed evidence in others (Jarocinska, 2006; León-Alfonso, 2007).

This paper is an effort addressed to integrate the different explanations of intergovernmental transfers. We focus on two different elements determining resource allocation: gains of Autonomous Communities (ACs) or regions in the periodical bargaining of its financing system and the most discretional program of earmarked grants: investment agreements made by the central government with subnational entities $^{2}$.

In this paper we show that no political variables affect the relative regional gains in bargaining, aside from the impact of public debt in some cases. In particular, only in the fourth system reform regional public debt stock was positively correlated with the gains in the financing system. Hence we show that the mechanism linking debt with higher transfers does not operate automatically and in a universal sense. We also show that intergovernmental transfers in the case of Spain are driven by the electoral interests of the national incumbent, but the preferred strategy is different depending on incentives provided by each level of competition. On the one hand, earmarked grants tend to be allocated in regions where there is a narrow margin of victory in regional elections, back-warding the idea of tactical investment centered on swing regions (Dahlberg and Johansson, 2002). On the other hand, incumbents tend to devote grants in those regions where they have better results at the national level, especially in those where there are more seats allocated, so they follow a "take care of your own" strategy (Cox and McCubbins, 1986; León-Alfonso, 2007). Then, both strategies are followed simultaneously by a political center interested in maximizing its chances in national elections and securing as many subnational governments as possible.

The structure of the paper is as follows. In section 2, the literature on political use of intergovernmental transfers and public investment is surveyed. The main hypothesis that has been presented by the literature are discussed and connected with

\footnotetext{
2 “Convenios de inversion” in Spanish.
} 
the Spanish case. In section 3 we present the variables used, the specifications and the econometric methodology. The next section summarizes the empirical results and discusses their substantive implications. Section 5 concludes.

\section{LITERATURE REVIEW}

A growing body of political economy literature has been centered on how incumbents use intergovernmental transfers for strategic purposes. The central idea of this approach is that political parties and candidates use redistributive policies as an instrument in order to maximize their electoral results, aside from other normative or efficiency considerations. This approach involves two assumptions. First, it assumes that politicians are mainly self-interested rent-seekers and they principally care about (re) election. Second, it assumes that voters are mainly interested in the private consumption derived from public policies investment. ${ }^{3}$ Based on those premises, the literature has investigated the political determinants driving this strategic use of transfers.

The first element that has been addressed is the (un)equal territorial distribution of political representation. According to this argument, Samuels and Snyder (2001) pointed out that policy agenda can be shaped by the level of malapportionment in the electoral system. This bias refers to those situations in which there are a mismatch between the share of legislative seats and the shares of population in a given district or region. As a consequence, the payoffs in terms of representation are altered depending on the region and politicians that want to take advantage of it. "In malapportioned systems, executives may thus face powerful incentives to build policy coalitions based on the 'cheap' support (for example, in terms of pork per vote) of legislators from overrepresented districts." (Samuels and Snyder, 2001: 667). Therefore, there are good reasons for expecting investment and transfers to over-represented districts.

This hypothesis has been addressed in different studies. Porto and Sanguinetti (2001) analyzed the effect of districts over-representation in Argentina's Congress in

\footnotetext{
${ }^{3}$ It is important to remind that depending on the author it holds under any circumstance (Cox and McCubbins, 1987) or it can be balanced by other elements such as partisan orientation (Dahlberg and Johansson, 2002)
} 
intergovernmental transfers. They showed that the federal government has tended to allocate over time important and continuing investments in those districts overrepresented in the Senate and the Chamber of Deputies. Similar studies have addressed this hypothesis considering the potential impact of the partisanship variable (Gibson et al., 1999) but it did not introduce changes concerning the main argument: the assemblies' apportionment determines the strategic use of investment and transfers. Evidence has supported this argument in other contexts. Hoover and Pecorino (2005) analyzed the impact of disproportional representation in federal expenditures in the United States. Rodden (2002) followed a similar logic in the study of EU redistribution among countries and Pitlik at al. (2006) found that malapportionment in the upper house in Germany leads to disproportional states share of per capita transfers among länders.

However, this explanation fails to point out the mechanisms driving strategic allocation in those countries where the apportionment of the legislature is perfect. Does the incumbent strategic allocation argument no longer hold? The literature has offered two competing theoretical arguments.

The first model is based on the theoretical background presented by Cox and McCubbins (1986). They divide voters into three different groups: support voters, opposition voters and swing voters. According to their conception, electoral politics is viewed as a two person game in which candidates' attitude towards risk is the crucial factor driving the stability of redistributive politics. The authors apply the same logic as in an investment. They argue that risk-adverse candidates will prefer to invest, especially in core supporters because they can expect a clear return in terms of electoral support. On the contrary, candidates' expectation of electoral support is lower among swing voters and even lower among opposition groups so they will allocate little investment in those groups. This strategy is based on the mobilization of the core voters of a party and has been labeled as "Hold what you got" or "Take care of your own" (Cox and McCubbins, 1986: 383).

The second theoretical model has deserved more attention explaining strategic allocation of transfers. This framework is based on papers by Lindbeck and Weibull (1993), Dixit and Londregan (1996, 1998) and Dahlberg and Johansson (2002). Those studies are focused on testing the "swing voters" and "core voters" approach to 
redistributive politics. For those voters considered as political moderate, those with no preferences on parties' manifestos, differences in resource allocation can be decisive in voting decision. It is the contrary in the case of core voters, who have a stronger party attachment and to which resource allocation plays little role. Assuming difference in preferences among the two groups, incumbents will invest resources in districts until reaching the specific point in which swing voters decide to vote for them. Dahlberg and Johansson (2002: 30) developed the idea further considering that low income voters have a higher marginal utility derived from income and thus, they can be persuaded to vote for the party providing them with more transfers. Then, the idea is to expect low income regions to receive higher transfers.

According to the density of the investment cut point, under some assumptions about the distribution ${ }^{4}$, there will be a correspondence with the closeness of the last election (Dahlberg and Johansson, 2002). Therefore, the hypothesis suggested according to this argument is the opposite of the previous one. In those districts where there is higher competitiveness in an electoral contest, the marginal utility of public investment will also be higher. As a result, swing states will be the primary target of strategic resource allocation. Studies dealing with this hypothesis have been centered on those programs fulfilling some conditions: Intergovernmental grants have to be dependent on the incumbent decision, the investment should be disentangled from efficiency and equity criteria, resources can be easily connected to an election and voters can identify if they have (not) been rewarded. The more recent evidence has been centered on Swedish intergovernmental transfer programs to municipalities, which fulfill the previous conditions (Johansson, 2003; Dahlberg and Johansson, 2002) and have proven the robustness of the hypothesis.

The study by Boex and Martinez-Vázquez (2005) distinguished several explanatory models in order to establish the institutional mechanism of grant allocation. However, they considered different case studies together and found a high consistency in the role played by political factors driving it. In that which concerns the political allocation of resources, they stressed the voter choice model; the allocation of intergovernmental grants will be distributed to local governments in accordance with the fiscal preferences of the median voter. On the other hand, they also underline the

\footnotetext{
${ }^{4}$ The assumption are symmetry and a single-peakedness distribution.
} 
important literature centered on institutional elements, especially regarding the hypothesis that "subnational government with powerful political interests can be expected to receive larger intergovernmental grants" (Boex and Martinez-Vázquez, 2005: 7). In a similar way, Veiga and Pinho study (2005) showed that specific local considerations matters. They proved that the longer the time span of the mayor in office, the more funds are transferred to his/her municipality. They also introduce the relevance of political timing, pointing out that grants increase in election years.

Therefore, interaction between central and subnational has been also pointed out as a crucial variable. Literature has suggested that intergovernmental transfers can be directly related with the incentives that an "opportunistic center" has to guarantee that his party controls the state government. Khemani (2003) studied the case of Indian federalism and argued that state governments are key bases in order to secure the incumbent party support at the national election because states can use instruments such as patronage in order to boost incumbents' political support. Therefore "National governments have political incentives to ensure that their party controls state governments, for which purpose it attempts to bias the distribution of national resources to political affiliated states" (Khemani, 2003: 9). This argument has been proven when Khemani shown that states in India belonging to the same party have higher deficits that are entirely financed by loans and transfers from the central government. In posterior research about India, Khemani (2007) proved that intergovernmental transfers are targeted to a particular type of partisan states. In specific, Khemani pointed out that "transfers determined by the political agency are greater to those co-partisan states where the party controls a smaller proportion of districts or seats allotted to the state in the national legislature" (Khemani, 2007: 466).

The Spanish case offers a perfect case study to test the strategic allocation of investments and intergovernmental grants for two reasons. The Spanish Constitution allowed a decentralization of the country which led to the creation of 17 Autonomous Communities (ACs). Due to historical and political reasons, two opposite financing systems emerged. Two ACs (the Basque country and Navarre), collect all taxes in their territories and transfer a part to the central state depending on its service provision. On the contrary, grants (both unconditional and conditional) and, in a lesser extent, tax sharing, have been, by and large, the main source of revenues for the remaining 15 ACs. 
Agreements on those instruments involve periodical renegotiation and opening up the possibility of rent-seeking (Lago-Peñas, 2005: 442).

There is a second reason to use Spain as a case study. A number of studies have been centered on how the electoral system can shape incentives towards public spending, the size of the government or the levels of redistribution (Persson and Tabellini, 2003; Boex and Martínez-Vazquez, 2005; Iversen and Soskice, 2006). However, little attention has been paid to how the electoral system can shape the allocation of intergovernmental transfers within a given country. According to previous arguments, the potential electoral gain for national incumbents can have a crucial mediating effect that could shape the optimal level of resource allocation to "take care of your own". This potential electoral revenue is captured by district magnitude. Spain is one country with important variance in district magnitude across constituencies in national elections (Monroe and Rose, 2002) and this can make the difference. The idea is that the marginal utility of intergovernmental transfers can be higher in those regions in which a higher number of national seats are allocated. Thus, this idea can only be tested in countries in which there is important variance in district magnitude in the national electoral system like the case of Spain.

The research dealing with the Autonomous Communities is scarce in general. In Lago-Peñas (2005) this topic is partially addressed in the discussion of regional debt bailout. Some evidence suggests that political affinity helps to explain the size of per capita investment agreements in those regions under the common financing system during the period between 1992-1996 and the relative gains in the financing system in 1991 (not in 1986). Nevertheless, those results should be considered with caution. The coefficients are statistically significant at a $10 \%$ level, the sample discards temporalseries analysis because it uses averages calculated between 1986-1996, and, fundamentally, the political affinity variable is roughly measured. It is considered that an autonomous community has political affinity if, during the period 1986-1996, the majority of years the party in office has been the same as the national incumbent PSOE.

In the case of investment agreements, Jarocinska (2006) discarded the relevance of political variables on its distribution over the period 1986-1996. However, in the case of direct transfers of the central state managed by the Autonomous Communities, she found that political affinity between regional and national government does not involve 
more per capita resources. However, it affects voters' loyalty because the percentage of "swing voters" is a relevant explanatory factor. The research of Leon-Alfonso (2007) provides evidence about the relevance of swing voters and partisan affinity. Her main contribution is centered on pointing out how the relative importance of both components changes with the institutional design. The lower the decentralization is, the more important the role played by partisan affinity and the less important the role played by swing voters. Gomez-Reino and Herrero (2011) change the scope and center their interest on explaining the annual evolution of the several grant programs to regions. Despite analyzing different political factors such as the affinity in the party ruling both levels, electoral margins, legislative agreements of single-minority governments at the national level with subnational parties or the incumbent electoral support in ACs, none of them proved to be statistically significant.

Our contribution is threefold. First, the gains in ordinary and regulated resources in reform moments are analyzed. Second, we estimate more complete specifications including political and economic mechanisms. Finally, we pay special attention to econometric methodology, especially to time series dynamics.

\section{VARIABLES, DATA, SPECIFICATIONS, AND ECONOMETRIC METHODS}

In order to test the systematic influence of the previously mentioned variables on the Autonomous Communities' resource distribution, we focus on those instruments in which their influence should be clearest: Revisions of ordinary ACs' financing system and earmarked grants from central administration to regional governments. Insofar as the dynamics of the former is ruled out by exogenous and common cross-region growth rates, it makes sense to not focus on the intra-period dynamic.

Therefore, two different endogenous variables will be analyzed. First, the gains (GAIN) obtained by each of the 15 Autonomous Communities under the common financing system ${ }^{5}$ on successive negotiation periods (1986-1991; 1992-1996; 20022008; 2009-2013). Second, the so-called "investment agreements"; earmarked grants

\footnotetext{
${ }^{5}$ The Basque Country and Navarre have their own financing system, bilaterally negotiated between the central government and each of the regions.
} 
distributed on a project basis $(G)$. As clarified above, these agreements are the grants category that can be more discretionally assigned by the central government. The first variable is expressed in percentages while the second is in Euros per capita.

The explanatory variables considered are the following:

1. The first set of political variables tries to capture the extent to which the national incumbent is centered on "taking care of your own" (Cox and McCubbins, 1986). The variable NAT measures the vote share obtained by the party in national government on each autonomous community. This variable takes into account national electoral cycle (PSOE until 1996; PP 1996-2004 and PSOE since then). If it is confirmed that national governments allocate more intergovernmental transfers in those communities where they do better, the optimal allocation threshold should be greater in those regions where there are a higher marginal utility, that is, in those where more seats are allocated. Therefore, if national votes prove to be statistically significant, we will test the interaction of NAT and the percentage of seats of the lower chamber "Congreso de los Diputados" allocated in each Autonomous Community $(M G)$. On the other hand, the $R E G$ variable measures the vote share of the national party in regional elections. For both $N A T$ and $R E G$ variables, lagged values are used in order to capture the idea that the national incumbent will reward those districts where it received more votes in previous election. For the same both variables (NAT-1 and REG-1) the expected coefficient is positive; the national incumbent will be allocated more transfers where he received more votes.

Third, we introduce in the specification political affinity $(P O L A F)$ between national and subnational incumbents (Khemani, 2003, 2007) ${ }^{6}$. This variable is defined in a different way in specifications [1] and [2] presented below. In specification [1] the variable is coded 1 if there are the same party in national and subnational government when the agreement is signed and 0 otherwise $^{7}$. In

\footnotetext{
${ }^{6}$ In the case of coalition governments at the regional level, we consider that there are political affinities if at least one of its members has the same political colour as the national incumbent.

${ }^{7} \mathrm{We}$ can include both this variable and individual fixed-effect thanks to the existence of asymmetries in elections cycles in the different Autonomous Communities. On the contrary, we have to set aside those variables in the case of the equation for GAIN due to the low within-variation inclusion. We also check to
} 
the case of investment agreements we adopt more severe criteria. Variable is coded 1 when the same parties are in both governments during both the passing and execution phases of the budgetary process. Additionally, we test if political affinity effect is stronger in electoral years (Veiga and Pinho, 2005).We have defined an $E L$ variable, which has value 1 in those years where national elections are held and 0 otherwise. In the econometric specification we include the interaction of POLAF and EL as well as the constitutive terms of the interaction in order to avoid biases in the coefficients (Brambor et al, 2006) ${ }^{8}$.

2. The second set of variables is centered on the extent to which national incumbents devote their investment efforts in those regions where there are more swing voters (Lindbeck y Weibull, 1993; Dixit y Londregan, 1996, 1998; Dahlberg y Johansson, 2002). We have measured regions as swing depending on the electoral competitiveness according to Dahlberg and Johansson (2002) and using the raw margin of votes between the first and the second party ( $v 1-v 2)$ (Söderlund et al., 2011). The DISN variable measures the vote share difference between first and second party at the national level in a given community. The $D I S R$ variable calculates the same difference but centered on the regional arena. The interpretation of the variables is the reverse of our hypothesis. The higher this variable is the less competitive is the election in this region and, as consequence, lower intergovernmental transfers and gains of financing system is expected.

3. The last set of political variables is related to the electoral gain of territories receiving transfers. On the one hand, more demographic weight involves more importance in the national parliament. Figure 1 shows the strong correlation between population share and seats allocated (Ceuta and Melilla are not considered). It presents a scatter plot combining both elements, the regression line and the curve derived from the use of a non-parametric technique (lowess linear fit). It gives a higher weight to the observations closer to each point.

define the variable in alternative ways, coding 1 in pre-election years and 0 otherwise; and also coding 1 in both electoral and pre-electoral years, and 0 otherwise. Results did not significantly change

${ }^{8}$ In the case of the interaction between $N A T$ and $M G$, the latter is not included as independent regressor because its within-variation is close o zero and then multicollinearity with individual fixed effects was extremely high. 
Linear correlation is positive and very strong $(r=+0.97)$. However, this relationship is not exactly proportional. Less populated regions tend to be overrepresented in the Parliament. This fact is graphically represented by a regression line starting over the bisectrix of the quadrant and ending below it. ${ }^{9}$. Therefore, more populated territories are more relevant in order to secure the national incumbent re-election despite the vote/ seat ratio tending to be higher. In electoral terms, according to the logic of strategic investment in case of malapportionment, more resources in small territories are allocated. Non parametric adjustment shows that this logic is not exactly the same in the case of $\mathrm{AC}$; they have a population of about 6 and $13 \%$ of the total caused by the diversity in the number of provinces. Therefore, we have introduced two extra variables in the estimates. The variable POPSHARE is defined as the population share of each autonomous community. Ceuta and Melilla have been excluded. Basque Country and Navarre are not considered in the specification centered on explaining the gains of the financing system. The second variable SEATS measures the relative share of seats of the Congress allocated in each autonomous community. Ceuta and Melilla have been excluded again.

4. Finally, we have included an economic variable: debt stocks of regional governments $(D)$. This inclusion is justified according to the literature centered on bailout to regional governments (Lago-Peñas, 2005). A positive and statistically significant coefficient would mean that there are implicit bailouts to those regional governments with more debt. The variable is expressed in thousands of Euros per capital. We have considered the value at the end of the previous year to the financing reform or the implementation of the investment agreements.

\footnotetext{
${ }^{9}$ This territorial proportionality deviation is due to the minimum of two seats per province established by electoral law. Ceuta and Melilla have one seat each. According to this division, 102 of the 350 seats of the Congress are fixed by province. The remaining 248 seats are distributed on a provincial basis according to their population.
} 
Figure 1: Relationship between population shares and seats.

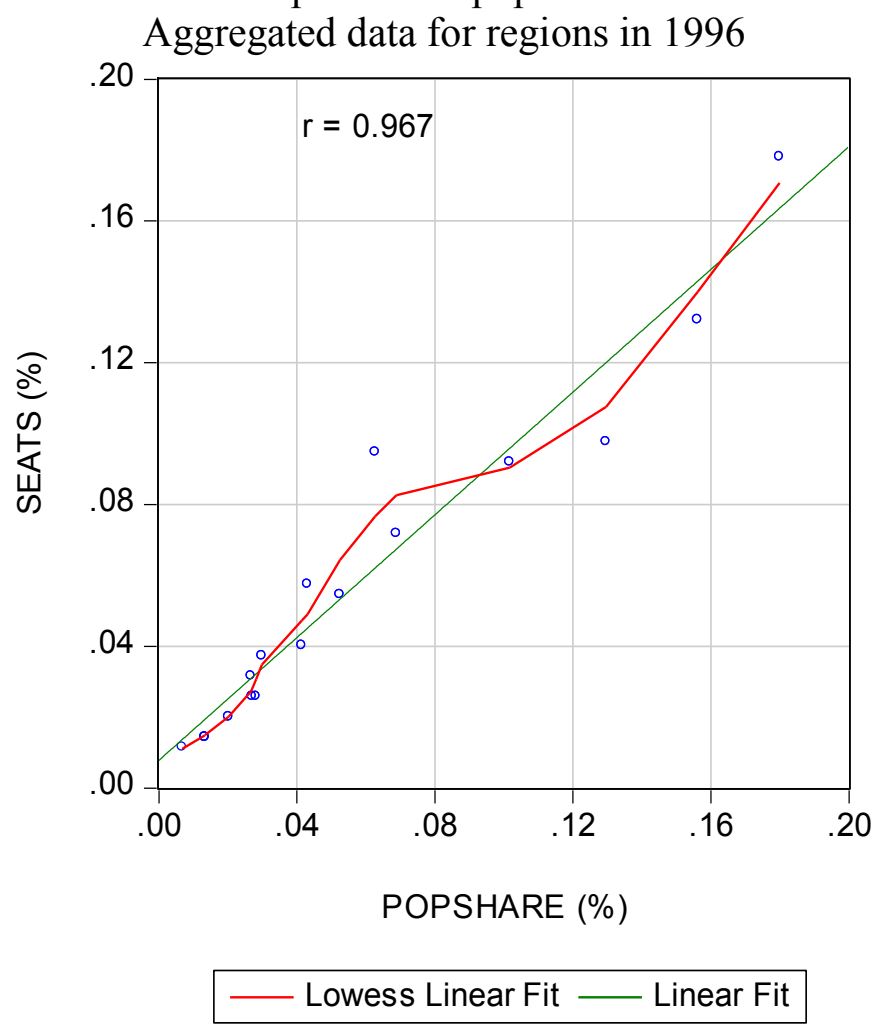

Sources: INE (www.ine.es), Ministerio del Interior (http://www.infoelectoral.mir.es/min/) and own elaboration.

Data sources are the following. Population data have been obtained from the National Statistics Institute of Spain (www.ine.es). Data on investment agreements are taken from BADESPE ( $\underline{\text { www.ief.es}}$ ). Data is available for the period 1986-2001. To measure the regional gains involved by bargaining on the financing system we rely upon the estimates by Utrilla (2002) for the reforms driving the periods 1987-1991, 1992-1996 and 2002-2008 and by Bosch (2011) for the period starting in $2009^{10}$. Electoral and political data are gathered from the official webpage of the Home Ministry (http://www.interior.gob.es/) and the several sites from this webpage devoted to national and regional elections.

Econometric Specifications and methodology

The following three econometric specifications are estimated:

\footnotetext{
${ }^{10}$ In the reform for the period 1997-2001 there were no increases in resources transferred to regions.
} 


$$
\begin{aligned}
& \operatorname{GAIN}_{i t}=\alpha_{t}+\delta_{1} \cdot N A T_{i t-1}+\delta_{2} \cdot P O L A F_{i t}+\delta_{3} \cdot D_{i t-1}+\varepsilon_{i t} \\
& G_{i t}=\alpha_{i}+\lambda_{t}+\beta_{1} \cdot N A T_{t-1}+\beta_{2} \cdot N A T_{t-1} \cdot M G_{i t}+\beta_{3} \cdot R E G_{i t-1}+\beta_{4} \cdot P O L A F_{i t}+ \\
& +\beta_{5} \cdot E L_{i t}+\beta_{6} \cdot E L \cdot P O L A F_{i t}+\beta_{7} \cdot D I S R_{i t}+\beta_{8} \cdot D I S N_{i t}+\beta_{9} \cdot D_{i t-1}+\varepsilon_{i t} \\
& F E_{i}=\alpha+\gamma_{1} \cdot \overline{P O P S H A R E}_{i}+\gamma_{1} \cdot \overline{\operatorname{SEATS}}_{i}+\mu_{i t}
\end{aligned}
$$

In all cases, subindex $\mathrm{i}$ and $\mathrm{t}$ indicate region and year, respectively, and $\varepsilon$ is a whitenoise random error. Individual fixed-effects are included in both specifications [1] and [2]. Time fixed-effects to account for common shocks are included in specification [3].

In the case of the endogenous variable $G A I N$, four cross-sections are merged yielding 60 observations $\left(15^{*} 4\right)$. Insofar as both time and cross-section dimensions of the sample are small, the use of specific panel data or time-series cross-section (TSCS) econometric techniques is discarded. On the contrary, we rely on OLS estimators, replacing standard residuals by general-form heteroskedasticty robust errors. Finally, according to the Breusch-Godfrey autocorrelation test, there are no problems in this respect. All the estimates are performed using the software Eviews 7.2.

In the case of specification [2] the first step is the analysis of the data generator process (DGP) of variable $G$. Hence several unit root tests were performed. One of the tests assumes the existence of common unit roots (Levin. Lin y Chu). The rest of them assume the existence of idiosyncratic unit roots (Im, Pesaran y Shin, Fisher-PP, FisherADF). In all cases, intercepts and time trends were included to avoid specification biases. Results are straightforward. Variable $G$ is I (0) or stationary: p-values were well below 0.01 in all cases. The straight consequence of this result is that the specification is formulated with the variables expressed in levels. Both time and individual fixed-effect are included in the specification. In the first case, it accounts for common shocks. In the second case, we test for the existence of systematic biases in the allocation of resources to the different regions ${ }^{11}$. In this case the extremely low within-variation of both POPSHARE and SEATS leads to a serious multicollinearity problem with individual fixed-effects. For this reason, both variables are dropped from the specification, and a

\footnotetext{
${ }^{11}$ Performed formal tests backed up the need of introducing both sorts of fixed-effects.
} 
second analysis is performed. Residuals are regressed on population shares to check if both variables are related. This is the logics of specification [3]. In order to deal with both heteroskedasticity and contemporaneous correlations in the random error, OLS standard errors are replaced by PCSE. Concerning autocorrelation, the first order coefficient was very low, around 0.2 and hence not a concern.

\section{RESULTS}

Tables 1 and 2 report the main descriptive statistics for the variables in specifications [1] and [2].

Table 1: Descriptive statistics of variables in Equation [1]. Stacked data

\begin{tabular}{|c|c|c|c|c|}
\hline & GAIN & NAT & POLAF & $D$ \\
\hline Mean & 7.27 & 44.89 & 0.62 & 0.53 \\
\hline Median & 6.40 & 44.05 & 1.00 & 0.40 \\
\hline Maximum & 32.10 & 60.70 & 1.00 & 2.43 \\
\hline Minimum & 0.80 & 22.80 & 0.00 & 0.00 \\
\hline Standard Deviation & 5.33 & 7.78 & 0.49 & 0.55 \\
\hline Observations & 60 & 60 & 60 & 60 \\
\hline Cross sections & 15 & 15 & 15 & 15 \\
\hline
\end{tabular}

Table 2: Descriptive statistics of variables in equations [2] and [3]. Stacked data

\begin{tabular}{|c|c|c|c|c|c|c|c|c|c|c|c|}
\hline & $G$ & DISR & $D I S N$ & $N A T$ & $R E G$ & POLAF & $E L$ & $P O L A F * E L$ & POPSHARE & SEATS & $D$ \\
\hline Mean & 14.24 & 12.45 & 10.60 & 41.39 & 38.44 & 0.51 & 0.26 & 0.099 & 0.058 & 9.58 & 0.39 \\
\hline Median & 10.16 & 12.01 & 9.20 & 40.80 & 39.46 & 1.00 & 0.00 & 0.00 & 0.040 & 9.15 & 0.33 \\
\hline Maximum & 131.85 & 32.73 & 34.40 & 58.10 & 54.28 & 1.00 & 1.00 & 1.00 & 0.18 & 15.38 & 1.62 \\
\hline Minimum & 0.006 & 0.150 & 0.20 & 18.00 & 9.51 & 0.00 & 0.00 & 0.00 & 0.006 & 6.32 & 0.000 \\
\hline Number of Observations & 272 & 272 & 272 & 272 & 272 & 272 & 272 & 272 & 272 & 272 & 272 \\
\hline Number of cross sections & 17 & 17 & 17 & 17 & 17 & 17 & 17 & 17 & 17 & 17 & 17 \\
\hline
\end{tabular}

Table 3 summarizes the estimates of specification [1]. In the first column none of the variables are statistically significant at the standard levels despite variable $D$ being marginally significant. In order to analyze in more detail the effect of this variable, it is interacted with a set of four dummy variables (T1 to T4). Variable $T 1$ is coded 1 for observations corresponding to the first reform and 0 otherwise, and so on. 
Results provide interesting evidence. During the eighties, when debt stocks were low, this variable does not matter at all. This situation changes in the '90s. The variable displays a p-value near $10 \%$. In the next decade the effect is statistically significant at a $5 \%$ level. The most surprising is the change in the coefficient sign between the third and fourth reforms. In terms of Spanish GDP, the average autonomic debt was almost the same in the time of both reforms, but the coefficient is negative in the first case and positive in the second ${ }^{12}$. Why is it that in one period that the higher the debt of the autonomous community, the higher the gains received, while in the second period the opposite is true?

Table 3: Econometric estimates of equation [1]

\begin{tabular}{|c|c|c|}
\hline Intercept & 1.47 & 8.68 \\
& $(0.26)$ & $(1.49)$ \\
\hline$N A T_{-1}$ & 0.09 & -0.08 \\
& $(0.75)$ & $(0.65)$ \\
\hline POLAF & 0.06 & 1.75 \\
& $(0.04)$ & $(0.93)$ \\
\hline$D_{-1}$ & 3.47 & \\
\hline$D_{-1} * T 1$ & $(1.52)$ & 33.57 \\
& & $(0.65)$ \\
\hline$D_{-1} * T 2$ & & 11.75 \\
& & $(1.59)$ \\
\hline$D_{-1} * T 3$ & & $\mathbf{- 5 . 9 5 * *}$ \\
& & $\mathbf{( 2 . 1 0 )}$ \\
\hline$D_{-1} * T 4$ & & $\mathbf{5 . 3 5 * *}$ \\
& & $\mathbf{( 2 . 1 6 )}$ \\
\hline Number of observations & 0.488 & 60 \\
\hline $\mathrm{R}^{2}$ & & 0.572 \\
\hline
\end{tabular}

Notes: Estimates include both individual and time fixe-effects. Computed t-statistics are robust to general form heteroskedasticity. ${ }^{* *}$ means statistical significance at $5 \%$ level.

First, reforms of federal financial relationships are based on multilateral bargaining between the central government and autonomous communities. Nevertheless, the demographic and electoral importance of Catalonia and its strong preference in favor of decentralization made this region the main agent in negotiations. The financial system reforms have depended to a higher extent on the parliamentary majorities in the Congress and the extent to which Catalan nationalist parties were decisive in the support of the national incumbent (Leon-Alfonso, 2008: 218). This factor was crucial in 2009 negotiations. The national government was a single majority

\footnotetext{
${ }^{12}$ Linear simple correlation between both variables for the reform passed in 2001 is -0.41
} 
party in parliament and it depended on the support of Catalan parties' MPs. Therefore, the central government was a much weaker player during this period.

Second, until 2001 those Autonomous Communities with more debt were the ones with higher levels of decentralization and powers, especially those with higher per capita GDP: the less developed (Galicia and Andalusia) enjoyed higher per capita budgets thanks to grants from both Spanish and European regional policy (Lago-Peñas, 2005 and 2006). The 2001 financing reform was in the middle of an expansive cycle and the problems related with the management of deficits, debt and fiscal consolidation were not a priority. The core of this reform was centered on the transference of health care systems in $10 \mathrm{AC}$, which, as was said, were the ones with lower debt stocks (RuizHuerta and Herrero, 2004). The health care system was, in fact, the main element driving the reform. "Health care financing is one of the main difficulties in the negotiation of the new model (...) This competence will involve important amounts of spending, so AC's are demanding that the national government provides guarantees enough that health care administration will not be a total disaster. The central government is in conditions of creating a fund with extra help to cover unplanned spending" 13 .

Nevertheless, in 2009 fiscal consolidation, debt and deficits were the key concerns. For example, the regional minister of finances from Catalonia argued that the economic crisis will reduce revenues and will create deficit. Nevertheless: "the [financing] system reform was necessary because it is structural, permanent, a new model affecting our income structure. It is a qualitative change. A different thing is the economic crisis. Even with a better model we still have deficits because it happens everywhere, even to better financed states". However the regional minister posited that: "The entry of 2.150 million of Euros in 2009 thanks to the new financing model will allow us to have fewer deficits than what we would have had with the other one" ${ }^{14}$.The fact that those $\mathrm{AC}$ with more debt had lower per capita financing allowed a relative improvement (Bosch, 2011).

\footnotetext{
${ }^{13}$ Newspaper "La Vanguardia". Friday, June 1 2001. p.19.

${ }^{14}$ Newspaper "La Vanguardia”. Sunday, August 9 2009. pp-59-60.
} 
Definitively, the mechanism linking debt with higher transfers does not seem to operate automatically and in a universal sense. It depends on the relative importance of subnational entities' debt, the relative power of the central government and regions in debt and the problems or challenges addressed as priorities in each discussion about the allocation of funds.

Estimates of specification [2] are reported in columns one to four of table 4. In column 5 the fixed effects estimated in the first column are regressed on variables with extremely low within-variation. Variables with statistical significance lower than $10 \%$ are EL, DISR and NAT. The variables DISR and NAT show the expected sign. Assuming that $P O L A F$ is included in the interaction, the negative coefficient of $E L$ points out that regional elections affect negatively the implementation of agreements.

Table 4: Econometric estimates of equations [2] and [3]

\begin{tabular}{|c|c|c|c|c|c|}
\hline Equation & [2] & [2] & [2] & [2] & [3] \\
\hline Intercept & $\begin{array}{c}9.29 \\
(1.52)\end{array}$ & $\begin{array}{c}8.88 \\
(1.49)\end{array}$ & $\begin{array}{c}15.75 * * \\
(2.11)\end{array}$ & $\begin{array}{c}10.62 * * * \\
(3.15)\end{array}$ & $\begin{array}{l}-8.05 \\
(0.88)\end{array}$ \\
\hline$N A T_{-1}$ & $\begin{array}{l}0.40 * \\
(1.94)\end{array}$ & $\begin{array}{l}0.25 * \\
(1.62)\end{array}$ & $\begin{array}{l}-0.24 \\
(0.79) \\
\end{array}$ & & \\
\hline$N A T_{-1} * M G$ & & & $\begin{array}{l}0.05 * * \\
(2.22)\end{array}$ & $\begin{array}{c}0.03 * * * \\
(3.03)\end{array}$ & \\
\hline$R E G_{-1}$ & $\begin{array}{l}-0.18 \\
(1.14)\end{array}$ & & & & \\
\hline POLAF & $\begin{array}{c}3.08 \\
(1.06)\end{array}$ & $\begin{array}{c}2.49 \\
(0.92)\end{array}$ & $\begin{array}{c}3.22 \\
(1.14)\end{array}$ & $\begin{array}{c}2.77 \\
(1.09)\end{array}$ & \\
\hline$E L$ & $\begin{array}{l}-3.58 * \\
(1.84)\end{array}$ & $\begin{array}{l}-3.33^{*} \\
(1.72)\end{array}$ & $\begin{array}{l}-2.89 \\
(1.47)\end{array}$ & $\begin{array}{l}-3.17^{*} \\
(1.69)\end{array}$ & \\
\hline$E L * P O L A F$ & $\begin{array}{l}1.26 \\
(0.35)\end{array}$ & $\begin{array}{c}1.53 \\
(0.39)\end{array}$ & $\begin{array}{c}0.66 \\
(0.18)\end{array}$ & $\begin{array}{c}0.91 \\
(0.25)\end{array}$ & \\
\hline DISR & $\begin{array}{c}-0.29 * * \\
(2.24) \\
\end{array}$ & $\begin{array}{c}-0.37 * * * \\
(3.20) \\
\end{array}$ & $\begin{array}{c}-0.33 * * * \\
(2.96) \\
\end{array}$ & $\begin{array}{c}-0.38 * * * \\
(3.61) \\
\end{array}$ & \\
\hline$D I S N$ & $\begin{array}{l}-0.08 \\
(0.58)\end{array}$ & & & & \\
\hline$D_{-1}$ & $\begin{array}{l}-0.002 \\
(0.39)\end{array}$ & $\begin{array}{l}-0.002 \\
(0.47)\end{array}$ & $\begin{array}{l}-0.001 \\
(0.28)\end{array}$ & $\begin{array}{l}-0.001 \\
(0.25)\end{array}$ & \\
\hline POPSHARE & & & & & $\begin{array}{l}9.450 \\
(0.28)\end{array}$ \\
\hline SEATS & & & & & $\begin{array}{c}0.8 \\
(0.95)\end{array}$ \\
\hline $\begin{array}{c}\text { Number of } \\
\text { observations }\end{array}$ & 272 & 272 & 272 & 272 & 17 \\
\hline $\mathrm{R}^{2}$ & 0.476 & 0.474 & 0.481 & 0.480 & 0.06 \\
\hline
\end{tabular}

Notes: Estimates in columns 1 to 4 include both time and individual fixed-effects and rely on PCSE proposed by Beck and Katz (1995) to compute t-statistics. *, **, *** means statistical sighnificance at $10 \%, 5 \%$ y $1 \%$ levels, respectively. 
The substantive explanation of $E L$ effect is related with the implementation of the agreements, which tend to be lower in electoral years contrary to Veiga and Pinho's (2005) hypothesis. The interaction of $E L$ and POLAF is not statistically significant so it means that there is no special investment effort in electoral year in those communities with the same parties in national and regional governments. The variable measuring the electoral distance between the first and the second party at the regional level DISR gives evidence in favor of the strategic investment of national governments in contested regions. The higher the electoral distance between the principal parties of the regional election (less competitive election), the lower is the investment in investment agreements. Therefore, the result is a higher level of investment in those AC where regional competition is important and the level of public investment can determine the final outcome of the election. The fact that REG-1 is not statistically significant confirms this idea.

Nevertheless, the electoral distance of the two main parties at the national level in a given region does not affect $G$. On the contrary, the vote share of the party at the national level NAT-1 has a statistically significant effect, so there is a positive association of the gains and the results of the party in a given AC. Therefore, at the national level the preferred strategy is to "take care of your own". When this variable interacts in the model with district magnitude it presents a positive and statistically significant result. This means that national incumbents do not "take care of their own" to the same extent in all regions but it is strategically determined by the potential seat gains of each region. The levels of investment will be higher in those regions where the national incumbents have more electoral support in previous election and have more seats at stake.

This evidence points out that hypotheses about the strategic use of investment agreements are complementary; one or the other will be preferred depending on the kind of election. There exist different optimal investment thresholds depending on the electoral contest. In the case of regional elections the optimal level of provision depends on the strategy of maximize the possibilities of changing a swing region irrespective of the levels of support the national incumbent has. Nevertheless, in national elections the objective is different because the potential threshold of investment is higher. The objective is not to change swing regions (which do not affect the final result because 
national constituencies are provinces) but mobilize the national incumbent strongholds as much as possible, especially those regions where more seats are allocated.

The argument of strategic use of intergovernmental transfers is similar to the one by Khemani (2007) when he says that, among co-partisan states, the ones in which it is preferred to invest are those with a lower proportion of seats controlled by the national incumbent. There is a kind of swing states among those owned by the party. The argument of our interaction is partially different. In Spain there is an importance variance in district magnitude (Monroe and Rose, 2002). Therefore, the expected utility of investment will vary depending on the number of seats allocated. If a "take care of your own" strategy is assumed, the expected electoral revenue will be higher the more the seats that $\mathrm{AC}$ has. This explains the positive sign of the interactive effect.

Finally, the variables POPSHARE and SEATS are not statistically significant. In the case of the second one the explanation can be related with the miss-adjustment between the AC and the district in national elections, the province. SEATS variable considers the share of MPs per capita of the AC. However, marginal seats linked with competitiveness (Blais and Lago, 2009) and malapportionment (Samuels and Snyder, 2001) should be calculated at the provincial level. Therefore, it is possible that its insignificant effect is driven by this problem, impossible to be solved with available data.

\section{CONCLUDING REMARKS}

Political officials in evolving federations may be tempted to use intergovernmental transfers and grants with strategic purposes. However, there is still an important lack of understanding on the institutional settings driving that behavior and the preferred tactic. In this paper we have addressed two different policies related with territorial resource allocation form the center: the gains of the Spanish regions or Autonomous Communities in the periodical negotiations of their financing system and the most discretional earmarked grants made by the central government to regional governments. This paper tests whether political variables related with electoral contest and their interaction are relevant in explaining their relative assignment across territories. We have shown that gains in the system of financing are unrelated with 
strategic use. The main factor driving those gains is regional public debt stocks. All in all the sign and magnitude of its effect depends on more factors, in particular the specific issues discussed in the inter-territorial negotiation.

However, the situation is quite different in the case of the intergovernmental transfers. Our argument is that two crucial elements will drive the preferred strategy in terms of their allocation: the arena of competition and the expected marginal gain. In regional contests, the national incumbents tend to allocate intergovernmental transfers in order to break a tie in elections and gain the subnational government. Nevertheless, the strategy is different in the case of national elections. In this case, the incumbent will prefer to distribute more money in those regions where it performs better in order to mobilize their voters but, especially in those regions in which there are more seats to be won. Then, both strategies are following simultaneously by a center interested in maximizing its chances in national elections and securing as many subnational governments as possible. 


\section{REFERENCES}

-Blais, A. and Lago, I. (2009): "A general measure of district competitiveness", Electoral Studies, 28 (1): 94-100.

-Brambor, Thomas; Clark, William; and Golder, Matt (2006): "Understanding Interaction Models: Improving Empirical Analyses" Political Analysis, 14(1): 63-82.

-Boex, J, and Martínez-Vázquez, J. (2004): "The determinants of the incidence of intergovernmental grants: A survey of the international experience", Public Finance and Management, IV(4): 454-479.

-Bosch, N. (2011): "La equidad horizontal en el modelo de financiación autonómica del 2009", in Informe IEB sobre federalismo fiscal 11, Barcelona: IEB. pp. 60-65 (http://www.ieb.ub.edu/aplicacio/fitxers/InformeFF2011_esp.pdf)

-Cox, G. and McCubbins, M. (1986): "Electoral politics as a redistributive game", The Journal of Politics, 48, 370-389.

-Dahlberg M. and Johansson E. (2002): "On the Vote-Purchasing Behaviour of Incumbent Governments”, American Political Science Review, 96(1): 27-40.

-Dixit, A. and Londregan, J. (1996): "The determinants of success of special interests in redistributive politics", The Journal of Politics, 58, 1132-1155.

-Dixit, A. and Londregan, J. (1998): "Fiscal federalism and redistributive politics", Journal of Public Economics, 68, 153-180.

-Gibson E., Calvo, E. and Falleti T. (1999): "Allocative Federalism: Legislative Overrepresentation and Public Spending in the Western Hemisphere", Working Paper, Northwestern University.

-Gómez-Reino J L and Herrero A, (2011): "Political determinants of regional financing: the case of Spain" Environment and Planning C: Government and Policy, 29(5), 802820 .

-Hoover, G. and Pecorino, P. (2005): "The political determinants of federal expenditure at the state level", Public Choice, 123 (1): 95-113.

-Iversen, T. and Soskice, D. (2006): "Electoral Institutions and the Politics of Coalitions: Why some democracies Redistribute more than Others", American Political Science Review, 100 (2): 165- 182.

-Jarocinsja, E (2006): 'Political economy of intergovernmental grants', (http://www.tesisenxarxa.net/TESIS_UPF/AVAILABLE/TDX-0105107-

$\underline{110151 / / \text { tej.pdf). }}$

-Johansson, E. (2003): "Intergovernmental grants as a tactical instrument: empirical evidence form Swedish municipalities", Journal of Public Economics, 87, 883-915.

-Khemani, S. (2003): "Partisan politics and intergovernmental transfers in India", Policy Research Working Paper, No.3016, Development Research Group, The World Bank. 
-Khemani, S. (2007): “The political economy of equalization transfers", en MartínezVázquez, J. and Searle, Bob (eds.), Fiscal equalization. Challenges in the design of intergovernmental transfers, New York: Springer, pp. 463-484.

-Lago-Peñas, S. (2005): "Evolving federations and Regional Public Deficits: testing the Bailout Hypothesis in the Spanish Case". Environment and Planning C: Government and Policy, 23: 317-474.

-Lago-Peñas, S. (2006): "Capital Grants and Regional Public Investiment in Spain: Fungibility of Aid or Crowding-in Effect?", Applied Economics, 38 (15): 1737-1748.

-León-Alfonso, S. (2007): The Political Economy of Fiscal decentralization. Bringing Politics to the Study of Intergovernmental Transfers, Barcelona: Institut d'Estudis Autonòmics.

-Lindbeck, A. and Weibull, J. (1993): "A Model of Political Equilibrium in a Representative Democracy”, Journal of Public Economics, 51: 195-209.

-Monroe, B. and Rose, A. (2002): "Electoral Systems and Unimagined Consequences: Partisan Effects of Districted Proportional Representation", American Journal of Political Science 46: 67-89.

-Persson, T. and Tabellini, G. (2003): The economic effects of Constitutions. Cambridge, Mit Press.

-Pitlik, H. Schneider F. and Strotmann, H. (2006): "Legislative Malapportionment and the Politicization of Germany's Intergovernmental Transfer System", Public Finance Review, 34: 637-662.

-Porto, A. and Sanguinetti, P. (2001): "Political determinants of intergovernmental grants: Evidence from Argentina", Economics and Politics, 13: 237-256.

-Rodden, J. (2002): "Strength in Numbers? Representation and redistribution in the European Union", European Union Politics, 3(2): 151.175.

-Ruiz-Huerta, J. and Herrero, A. (2004): "El sistema de financiación autonómica aprobado en 2001: una valoración a partir de la liquidación del año 2002", Informe de las Comunidades Autónomas 2004, Instituto de Derecho Público.

-Samuels, D. and Snyder, R. (2001): "The Value of a Vote: Malapportionment in Comparative Perspective", British Journal of Political Science, 31: 651-671.

-Söderlund, P, Wass, H. and Blais, A. (2011): "The impact of motivational and contextual factors on turnout in first-and second-order elections", Electoral Studies, 30: 689-699.

-Utrilla, A. (2002): "Los efectos del Nuevo sistema de financiación autonómico sobre la suficiencia y la equidad", in Salinas, J. (Ed.): El nuevo modelo de financiación autonómica (2002), Madrid: IEF, pp. 61-110. 
-Veiga, Linda and Pinho, M.M. (2005): "The political economy of Portuguese intergovernmental grants", NIPE Working Paper 8/2005, (http://papers.ssrn.com/sol3/papers.cfm?abstract_id=830104). 